\title{
断層シュリーレン法を用いた超音速複葉翼の内部構造の解明*1 Analysis of Shock-Wave Structures in a Supersonic Biplane by Focusing Schlieren Technique
}

\author{
萩 原 真 澄*2,*3 · 永 井 大 樹*2 $\cdot$ 沼 田 大 樹*2 ·浅 井 圭 介*2 \\ Masumi Hagiwara, Hiroki Nagai, Daiju Numata and Keisuke Asai
}

Key Words : Supersonic Biplane, Focusing Schlieren Method, Pressure-Sensitive Paint

\begin{abstract}
The flow field in a three dimensional biplane model is investigated by using a focusing schlieren method which can visualize a density gradient of arbitrary cross sections along a light path. Experiments were conducted in the $60 \mathrm{~mm} \times 60 \mathrm{~mm}$ indraft supersonic wind tunnel at the Institute of Fluid Science, Tohoku University at $M_{\infty}=1.7$. Two test models were used in this experiment: the two-dimensional and three-dimensional models. First of all, the performance of the focusing schlieren system was evaluated by using the two dimensional model. The flow visualization in the three dimensional model is conducted by using the conventional schlieren method and more detail flow visualization by using the focusing schlieren method. Additionally, surface pressure distribution is measured by using the pressuresensitive paint (PSP). From combined measurements, the flow field in the three dimensional model was discussed. It was found that shock wave structures in the test model vary in the span direction. Additionally, the cause of high pressure regions on the wing surface was understood by comparing with the PSP result.
\end{abstract}

\section{記}

号

$a:$ カットオフグリッド上の光源像高さ

$A:$ レンズロ径

$b:$ カットオフグリッドのグリッド間隔

$c:$ コード長

$f:$ 焦点距離

$F:$ 絞り值

$G:$ 翼間距離

$l:$ カメラレンズから測定断面までの距離

$l^{\prime}$ : カメラレンズからスクリーンまでの距離

$L$ : カメラレンズからソースグリッドまでの距離

$L^{\prime}$ : カメラレンズからカットオフグリッドまでの距離

$M_{\infty}$ : マッハ数

$n$ : カットオフグリッドの $1 \mathrm{~mm}$ あたりのスリット数

$s:$ スパン長

$t:$ 翼厚

$w$ : 分解能

$\Delta z_{1}$ : 鮮明焦点深度

$\Delta z_{2}:$ 不鮮明焦点深度

$\alpha:$ ソースグリッドのグリッド幅

$\beta:$ ソースグリッドのグリッド間隔

*1 (C) 2012 日本航空宇宙学会

平成 22 年 3 月 10 日, 日本航空宇宙学会北部支部 2010 年講演 会ならびに第 11 回再使用宇宙輸送系シンポジウムにおいて発表. 平成 23 年 8 月 11 日原稿受付

*2 東北大学大学院工学研究科

*3 現 関東自動車工業 (株)

\author{
$\delta:$ 許容錯乱円 \\ $\varepsilon_{\min }:$ 感度 \\ $\lambda$ : 波長 \\ $\phi:$ 像数
}

\section{1. 研 究 背 景}

次世代超音速旅客機の開発を実現させるにあたり,ソニッ クブームの低減が重要な課題となっている。ソニックブー ム低減法の 1 つして 1935 年に Adolf Busemann によっ て超音速複葉翼理論が提唱され, 現在, この理論を応用し た研究が楠瀬らによって行われている ${ }^{1,2)}$. 超音速複葉翼は ダイヤモンド翼を翼弦を境にして半分にカットし，翼の凸 部分が向い合う形に配置したもので，超音速流中で翼前縁 から生じる衝撃波を稜線から生じる浢張波によってキャン セルすることができる。この効果を利用することで, 超音 速複葉翼はソニックブームと造波抵抗を大幅に減衰させる ことが可能となる.

これまで, 超音速複葉翼研究は理論的考察と Computational Fluid Dynamics (CFD) を用いた空力特性に関する ものが中心であり，2 次元及び 3 次元の翼型形状や胴体形 状 ${ }^{3-5)}$, さらには逆問題設計6) などに関する研究が進められ ている. しかしながら, 非定常現象を含む 3 次元流れ場の計 算は一般的に困難であり, 翼間の流れ場についての議論は限 られている。 そのため, これら CFD 結果の検証に加え, 不 始動から始動への遷移過程や翼端周りの流れ場などを理解す ることを目的として, 感圧塗料 (Pressure-Sensitive-Paint, PSP) 7 9) やシュリーレン法を用いた実験的な研究10) が実 


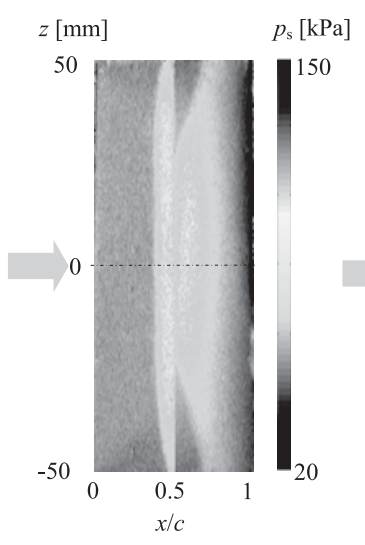

第1図 表面圧力分布 ${ }^{10)}$ $M_{\infty}=1.7$

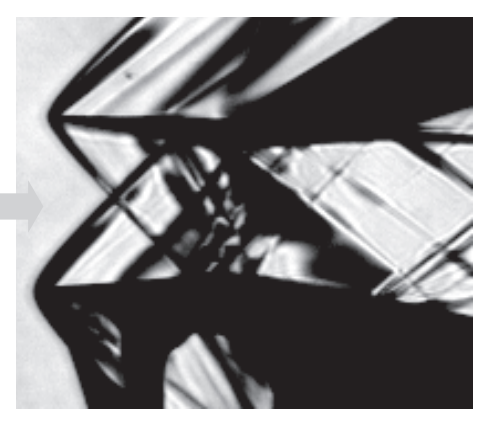

第 2 図 シュリーレン可視化 ${ }^{10)}$ $M_{\infty}=1.7$

施されている.

Nagai ら ${ }^{10)}$ は, マッハ数 $M_{\infty}=1.7$ で始動する超音速 複葉翼間の流れ場の解明を目指し, PSP を用いて翼面上の 圧力分布（第 1 図）を，さらにはシュリーレン法を用いて 翼間流れ場の可視化（第 2 図）を試みた。理論上，翼端部 を除き超音速複葉翼内の圧力分布は一定となるが, 第 1 図 に示すように，翼面上には衝撃波/衝撃波干渉に起因する 3 次元的かつ複雑な圧力分布が生じた。 また, 第 2 図に示す シュリーレン法を用いた可視化によっても翼間内の複雑な 衝撃波構造の存在が認められたが, PSPによる計測結果か ら推定される翼間内の複雑な衝撃波構造を, 空間位置情報 を含めた形で捉えることはできなかった。

従来のシュリーレン法では原理上, 全光路長の密度変化 が積分される，すなわちスパン方向の各位置で生じる衝撃 波が 1 枚の画像上にすべて重ね合わされる形で投影されて しまうため, 空間上の各位置での詳細な衝撃波構造を明確 には特定できない. そのため, 複葉翼内部流れのような 3 次元的な構造を持つ現象に従来のシュリーレン法を適用し た場合，現象的な議論を行うことは困難である。

このような従来のシュリーレン法の問題を解決する方法 として, 任意の断面における密度変化を可視化できる断層 シュリーレン法 ${ }^{11 \sim 13)}$ がある. この手法は光路長の任意断面 を選択的に可視化することが可能であり, 従来のシュリーレ ン法では判別が困難であった翼間内の複雑な衝撃波構造を 明らかにすることが期待できる。また PSP 計測結果と組み 合わせることで, より詳細な翼間流れの把握が可能となる.

そこで本研究では, 断層シュリーレン光学系を設計・製 作し, 翼間内に生じる 3 次元的な衝撃波構造の解明を目的 とする.

実験では，まず PSP を用いた翼表面圧力場計測を行い， 翼間内に生じる衝撃波及び膨張波が翼面上に与える影響を 調べた. 次に設計・製作した断層シュリーレン光学系を用 いてスパン方向に一定間隔を持った断面に分割し, 各位置 における衝撃波構造を可視化計測した。最終的に, これら の計測結果を複合的に組み合わせることにより 3 次元翼内 部の流れ場の議論を行う.

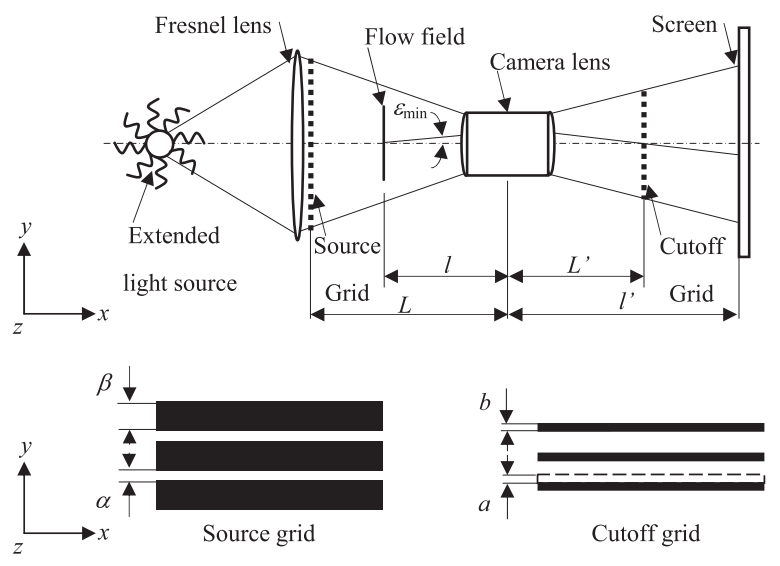

第 3 図 断層シュリーレン光学系

\section{2. 計 測 手 法}

\section{1 断層シュリーレン法}

2.1 .1 基本構成 断層シュリーレン光学系の構成図を第 3 図に示す。光学系は, テストセクションに対して均一な 光を照射する拡散光源, 全光束を集光するフレネルレンズ, 多光源となるソースグリッド, フレネルレンズから集光し た光束を再び拡散させるためのカメラレンズ, ナイフエッ ジの代わりとなるカットオフグリッド, そしてスクリーン によって構成される。 なお, 図中の記号 $\varepsilon_{\min }$ は光の偏角, $l, l^{\prime}, L, L^{\prime}$ はカメラレンズから各構成部までの距離, $\alpha, \beta$ はソースグリッドのグリッド幅及びグリッド間隔, $a, b$ は 光源像高さ及びカットオフグリッドのグリッド間隔を示す.

2.1 .2 感度 Weinstein ${ }^{14)}$ は密度変化による輝度の最小 変化を $10 \%$ と仮定し, 断層シュリーレン法の感度 $\varepsilon_{\min }$ を 以下のように定義した, この $\varepsilon_{\min }$ の範囲は $2 \sim 16 \operatorname{arcsec}$ と されている13).

$$
\varepsilon_{\min }=20606 \frac{a L}{L^{\prime}(L-l)}
$$

この式より，断層シュリーレン法の感度を上げるためには， $10 \%$ の輝度変化を少ない屈折角で達成することが望ましい. すなわち, カメラレンズからソースグリッドまでの距離 $L$ を大きくし, カメラレンズから被写体までの距離 $l$ を小さ くし, さらに光源像高さ $a$ を小さくすれば良い.

2.1 .3 分解能 断層シュリーレン法ではカットオフグリッ ドによる回折の影響がスクリーン上に投影される像の鮮明 さに制限をかける。測定位置からスクリーンまでの像倍率 を考慮すると, 測定位置における単一スリットの分解能 $w$ は入を光源の波長とすると以下のように定義される13).

$$
w=\frac{2 \lambda\left(l^{\prime}-L^{\prime}\right) l}{l^{\prime} b}
$$

2.1 .4 焦点深度 断層シュリーレン法の特徵は光路長の 任意断面を可視化できることである，そのため, Weinstein は焦点深度として許容錯乱円 $\delta$ の大きさを $w \mathrm{~mm}$ 及び $2 \mathrm{~mm}$ とそれぞれ考え, 鮮明焦点深度 $\Delta z_{1}$, 不鮮明焦点深度 $\Delta z_{2}$ を次式で定義した13). 


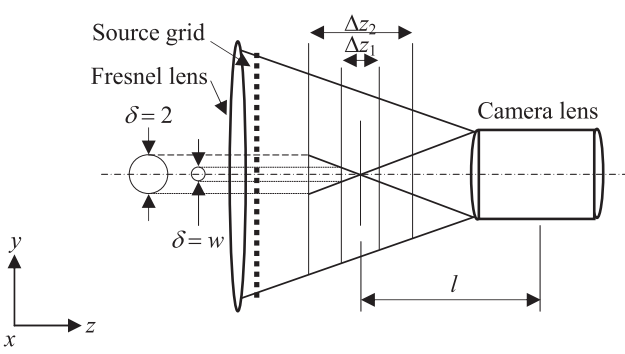

第 4 図 焦点深度概念図

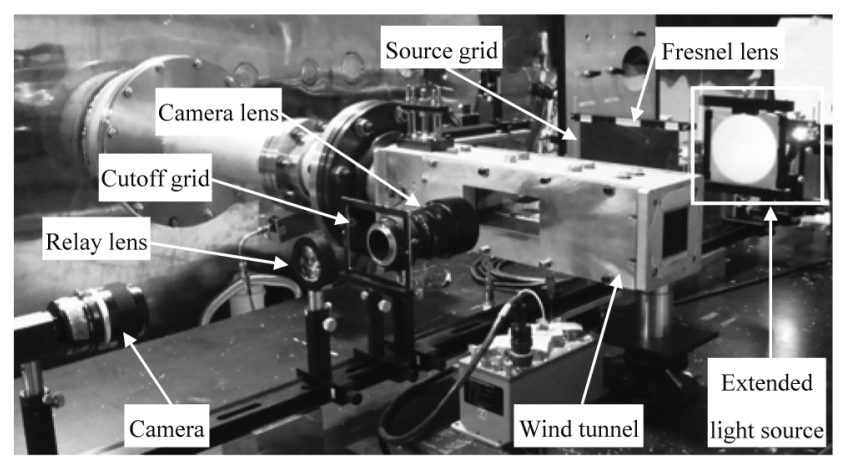

第 5 図＼cjkstart断層シュリーレン光学系

$$
\begin{aligned}
& \Delta z_{1}=2 \frac{w l F}{f} \\
& \Delta z_{2}=2 \frac{2 l F}{f}
\end{aligned}
$$

ここで, $f, F$ はカメラレンズの焦点距離及び絞り值であ る.なお，係数 2 はフォーカスの合う位置が前後で等しい と仮定することで決められた值である。

鮮明焦点深度とはテストセクション内の最もフォーカスの 合った位置を中心に直径 $w \mathrm{~mm}$ の大きさで鮮明にスクリー ン上に結像する範囲である。また，不鮮明焦点深度とはテ ストセクション内の最もフォーカスの合った位置を中心に 直径 $2 \mathrm{~mm}$ の大きさでスクリーン上に結像する範囲であり, この值を超えた領域ではスクリーン上で不鮮明に像が結ば れる。第 4 図に焦点深度の概念図を示す。

2.1 .5 カットオフグリッド カットオフグリッドは従来 のシュリーレン法におけるナイフエッジに相当し, 密度変 化により屈折した光路の一部を遮断する機能を有している. 断層シュリーレン法は多重像の重ね合わせによって断面画 像が可視化される。 スクリーンに投影される多重像の数 $\phi$ は次式に示される13).

$$
\phi=\frac{n f\left(l^{\prime}-L^{\prime}\right)}{2 F l^{\prime}}
$$

ここで $n$ はカットオフグリッドの $1 \mathrm{~mm}$ あたりのスリット の本数である.

2.1.6 任意断面の撮影方法 断層シュリーレン法を用い て任意断面を撮影する場合，(a) 測定位置にフォーカスが 合うようにスクリーンを移動する，(b) スクリーンにフォー カスが合うように測定対象そのものを移動する, 及び (c) スクリーンにフォーカスが合うように全光学系を移動する
第 1 表 断層シュリーレン光学系諸元

\begin{tabular}{ccccc}
\hline$\lambda[\mathrm{mm}]$ & $f[\mathrm{~mm}]$ & $F$ & $l[\mathrm{~mm}]$ & $L[\mathrm{~mm}]$ \\
$4.7 \times 10^{-4}$ & 85 & 1.4 & 150 & 460 \\
\hline$l^{\prime}[\mathrm{mm}]$ & $L^{\prime}[\mathrm{mm}]$ & $\varepsilon_{\min }[\operatorname{arcsec}]$ & $\Delta z_{1}[\mathrm{~mm}]$ & $\Delta z_{2}[\mathrm{~mm}]$ \\
196.15 & 104.27 & 11.74 & 0.52 & 9.88 \\
\hline$w[\mathrm{~mm}]$ & $n[$ line $/ \mathrm{mm}]$ & $a[\mathrm{~mm}]$ & $b[\mathrm{~mm}]$ & $\alpha[\mathrm{mm}]$ \\
0.1 & 1.41 & 0.04 & 0.63 & 0.35 \\
\hline$\beta[\mathrm{mm}]$ & $\phi$ & & & \\
2.78 & 20 & & & \\
\hline
\end{tabular}

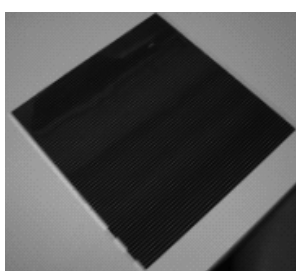

第 6 図 ソースグリッド

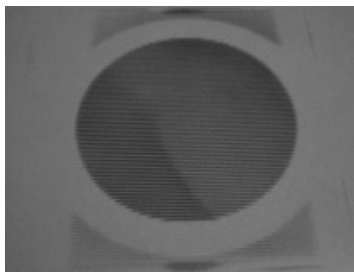

第 7 図カットオフグリッド という方法が考えられる。(a)を選択した場合，断層シュ リーレン光学系の一部を変化させるため, これまで挙げた 断層シュリーレン光学系のパラメータ, なかでも最も重要 な不鮮明焦点深度が変化してしまい, 常に同じ条件で各位 置でのシュリーレン画像を撮影することができない. (b), （c）を選択した場合，これらの全パラメータは一定となる が (b) の方法では風洞そのものを移動させることは非常に 困難であるため，この方法は採ることができない．よって 本研究では (c) の光学装置全体を移動させる方法を採用す る。このシステムを採用すると, 通風時間中に任意の断面 を連続的に撮影することが可能となる.

2.1.7 断層シュリーレン光学系セットアップ 第 5 図に 断層シュリーレン光学系セットアップ写真を, そして第 1 表 に当該光学系の諸元を示す。使用した実験機器は, 拡散光 源としてスポット光源（浜松ホトニクス，L8868-04），第 1 拡散板, 平凸レンズ (シグマ光機, 焦点距離 $f=300 \mathrm{~mm}$, 有効径 $A=100 \mathrm{~mm}$ ) 及び第 2 拡散板（マイラーフィル ム）を組み合わせて使用した。次に光源からの全光束を 集光するためのフレネルレンズ（日本特殊光学樹脂, 焦点 距離 $f=370 \mathrm{~mm}$, 有効径 $200 \times 200 \mathrm{~mm}$ ), 多光源とな るソースグリッド, フレネルレンズから集光した全光束を 再び拡散させるためのカメラレンズ（コシナ, PLANART $1.4 / 85 \mathrm{ZF}$, 焦点距離 $f=85 \mathrm{~mm}$, 絞り $F=1.4)$, 光源像 の一部を遮断するカットオフグリッド, リレーレンズ（アク ロマティックレンズ, シグマ光機, 焦点距離 $f=80 \mathrm{~mm}$, 有 効径 $A=50 \mathrm{~mm}$ ） と続く. 撮影カメラは $10 \mathrm{bit}$ CCD カメ ラ（池上通信機，SKC-145T2）を用い, 単焦点レンズ（二 コン, Nikkor $35 \mathrm{~mm} \mathrm{f} / 1.4$, 焦点距離 $f=35 \mathrm{~mm}$, 絞り $F=1.4 ）$ を取り付けた。 空間分解能は $1000 \times 1000$ pixel である。ソースグリッド（第 6 図）は，製作の容易な点や 低コストな点から OHP シートにスリットパターンを印刷 したものを使用した。 また，カットオフグリッド（第 7 図） には， $4 \times 5$ inch フィルム（富士フィルム, neopan 100）に ソースグリッド像を感光させ，現像したものを使用した。 


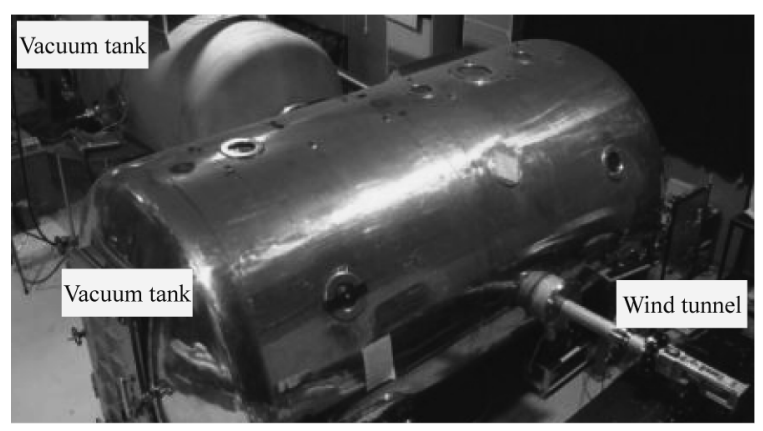

第 8 図 超音速風洞全体図

第 2 表 超音速風洞諸元

\begin{tabular}{ll}
\hline Drive system & Indraft type \\
Cross-sectional area $[\mathrm{mm} \times \mathrm{mm}]$ & $60(\mathrm{~W}) \times 60(\mathrm{H})$ \\
Design Mach number $M_{\infty}$ & 1.7 \\
Driving gas & Air \\
Duration time $t[\mathrm{sec}]$ & 30 \\
Total pressure $p_{0}[\mathrm{kPa}]$ & Atmospheric pressure \\
Total temperature $T_{0}[\mathrm{~K}]$ & Ambient temperature \\
\hline
\end{tabular}
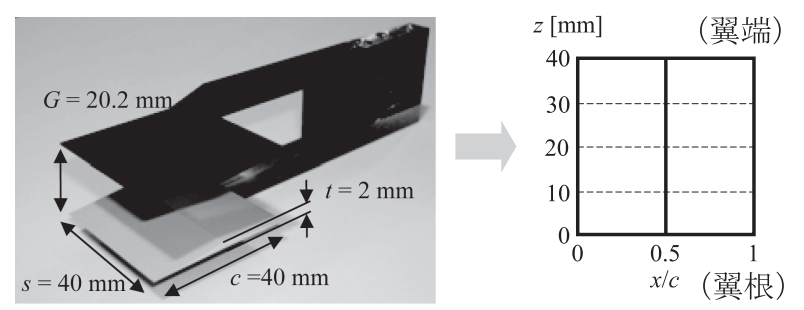

第 9 図 3 次元模型

第 10 図 3 次元模型の座標系

\section{2 シュリーレン法}

2.2 .1 シュリーレン光学系セットアップ シュリーレン 光学系に用いた実験機器は凹面鏡（シグマ光機, 焦点距離 $f=1500 \mathrm{~mm}$, 有効径 $A=150 \mathrm{~mm}$ ）とナイフエッジであ

る. 光源と撮影カメラは断層シュリーレン光学系と同様で ある。

\subsection{PSP 計測手法}

2.3.1 PSP 光学系セットアップ 本研究では, PSP の 色素としてPtTFPPを用いた. PtTFPP はポルフィリン 系化合物であり， $400 \mathrm{~nm}, 650 \mathrm{~nm}$ にそれぞれ励起と発光 のピーク波長を持つ. バインダとして使用したPoly (IBMco-TFEM) は多孔質のポリマーであり, 気体透過性に優れ ている15)。溶媒としてトルエンを用いた。

また本研究では励起光源として，2 基の UV-LED を使 用した。 UV-LED のピーク波長は $395 \mathrm{~nm}$ である. LED の前方には $400 \pm 50 \mathrm{~nm}$ のバンドパスフィルタを取り付け てあり，実験で使用する感圧塗料の励起波長だけを通過さ せている. 発光強度画像取得には $\mathrm{A} / \mathrm{D}$ 分解能 12 bit の素 子冷却型 CCD カメラ (浜松ホトニクス, C4742-80-12AG) を用いた。空間分解能は $1344 \times 1024$ pixel である。また発 光波長のみを検出するために, $650 \pm 20 \mathrm{~nm}$ のバンドパス フィルタをカメラレンズの前に取り付けた。

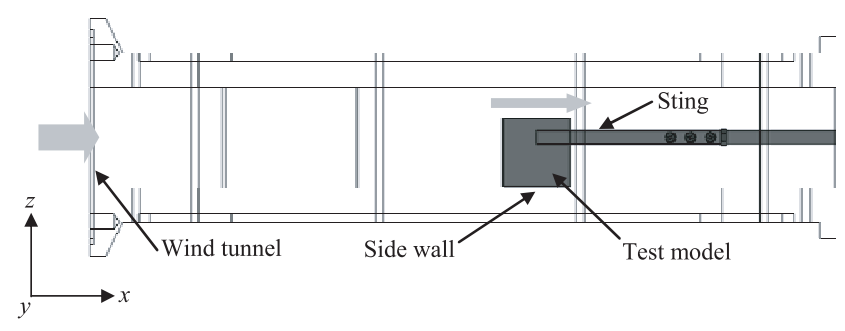

第 11 図超音速風洞上面図

第 3 表 実験条件, マッハ数 $M_{\infty}=1.7$, 迎角 A.O.A. $=0 \mathrm{deg}$

\begin{tabular}{lll}
\hline Test model & Optical method & Measurement location $z[\mathrm{~mm}]$ \\
\hline \multirow{3}{*}{ 3-D model } & PSP & Schlieren \\
& Focusing schlieren & $0,5,10,15,20,25,30,35,40$ \\
\hline
\end{tabular}

2.4 風洞 本実験は流体科学研究所が所有する大気吸 い込み式超音速風洞を利用した。風洞外観を第 8 図に, そ して第 2 表にその諸元をまとめる.

2.5 実験模型 本実験で用いた模型の形状は設計マッ 八数 $M_{\infty}=1.7$ にて衝撃波干渉/相殺を実現できる基本形 状である。第 9 図に 3 次元模型を示す。模型の仕様は翼弦 長 $c=40 \mathrm{~mm}$, 翼厚 $t=2 \mathrm{~mm}$, 楔角 $\varepsilon=5.71 \mathrm{deg}$, 翼幅 $s=40 \mathrm{~mm}$ である。 また, 下翼翼面上の座標を規定した図 を第 10 図に示す。模型は第 11 図に示すようにテストセク ション下流側からの後方支持によって流れ場内に固定して いる。 また, 図中の模型下側は風洞壁近傍に位置しており, 上側は主流にさらされる。なお, 感圧塗料は下翼の上面に 塗装されており，それ以外の部分は光の反射を防ぐために 黒色ペイントで塗装した，翼の材質はSUS304である.

2.6 実験条件 第 3 表に風洞実験条件を示す.

\section{3. 実 験 結 果}

\subsection{3 次元模型を用いた超音速複葉翼内流れの可視化}

第 12 図に, PSP 計測から得られた 3 次元模型下翼表面の 圧力分布を示す。この画像の上側が主流にさらされる翼端 であり，下側が風洞壁面近傍に位置する。また，第 13 図に シュリーレン可視化画像を示す.

第 12 図より翼前縁部の両端からマッハコーンが見られ, これにより超音速複葉翼として始動していることがわかる. また，マッハコーンの角度が左右それぞれ異なっているが， これは風洞壁面側で発達した境界層の影響により気流が減速 し, 衝撃波角が広がったためと考えられる. 次に $x / c=0.5$ の上流側では，壁面側の高圧力領域 $\mathrm{A}$ が生じているのがわ かる. また $x / c=0.25 \sim 0.5$ の間で, 弓形状の高圧力領域 $\mathrm{B}$ がスパン方向に広がっているのがわかる. $x / c=0.5$ の 下流側では，両翼端から膨張波による低圧力領域 C, D が 見られ, 壁面側の低圧力領域 $\mathrm{C}$ は狭く, 翼端側では広範囲 に低圧力領域 D が広がっている。また $x / c=0.75$ では高 圧力領域 $\mathrm{E}$ がスパン方向に生じており, この高圧力領域 $\mathrm{E}$ は $z=10 \sim 15 \mathrm{~mm}$ の間が最も圧力が高くなっている.こ の領域は壁面側から翼端側に向かって右斜め上方へ伸びて 


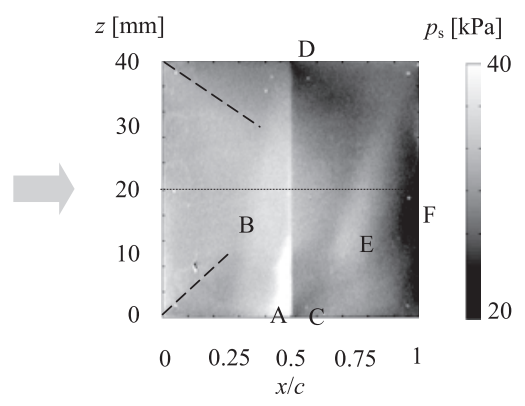

第 12 図 表面圧力分布

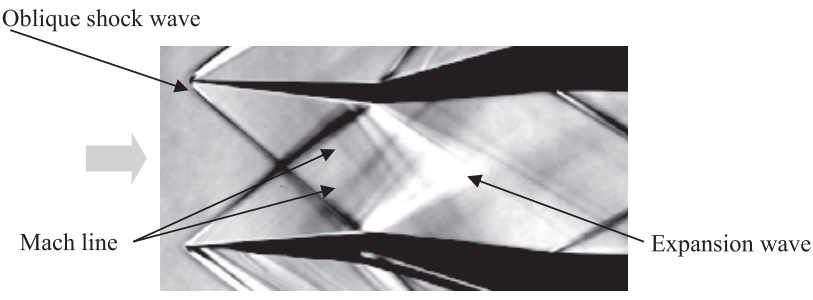

第13図 シュリーレン可視化結果

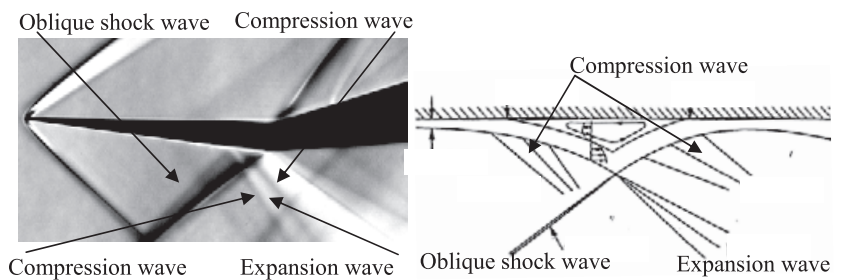

第14図上翼拡大図

第 15 図 模式図 ${ }^{16)}$

おり，翼端に向かうごとに高圧力領域 $\mathrm{E}$ は減少している。 そして $x / c=1$ では, 翼上面の稜線から発生した膨張波に よって低圧力領域 $\mathrm{F}$ は $z=0 \sim 30 \mathrm{~mm}$ まで及んでいる。 こ のような圧力分布は衝撃波/衝撃波, 衝撃波/境界層干渉に よる影響であると考えられる。

一方，第 13 図のシュリーレン画像では，ほぼ 2 次元理 論通りの衝撃波構造をしていることから, 翼前縁から生じ る斜め衝撃波は翼弦中央の厚みが最大となるところ（稜線） に達し，稜線から生じる膨張波によってほぼ相殺されてい ることがわかる。

まず，翼前縁部から稜線までの中間で複数のマッハ線が表 れている。そして衝撃波角の異なる斜め衝撃波が可視化され ている。この衝撃波の到達位置に膨張波, 及びその前後で圧 縮波が確認できる。この領域を拡大したシュリーレン画像を 第 14 図に示す。ここでシュリーレン計測時, 翼前縁部から稜 線までの距離を基準にしたレイノルズ数は $R e=3.03 \times 10^{5}$ であり, 模型表面の境界層は層流となっており, 第 15 図に 示すような層流モデル16)の衝撃波構造になっていると考え られる。この構造は斜め衝撃波の入射によって模型表面の 境界層がはく離し, 持ち上げられ, 境界層外縁が凹面状と なるため，圧縮波が発生している，また，はく離によって境 界層の外縁が凸面状になることにより発生する膨張波, 及 びその下流で境界層の外縁が再び凹面状になることにより

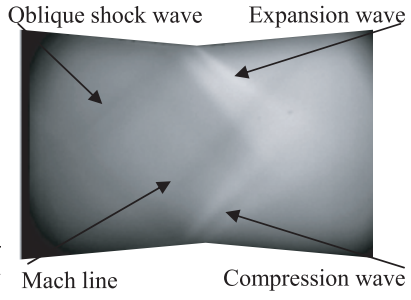

(a) $z=0 \mathrm{~mm}$

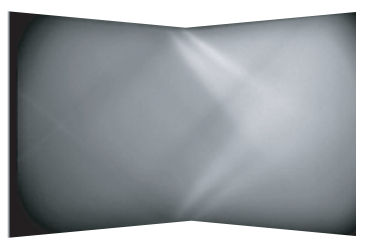

(b) $z=5 \mathrm{~mm}$

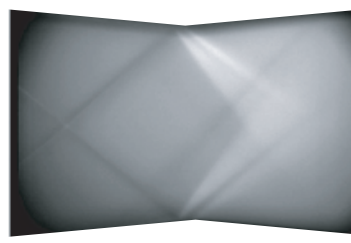

(d) $z=15 \mathrm{~mm}$

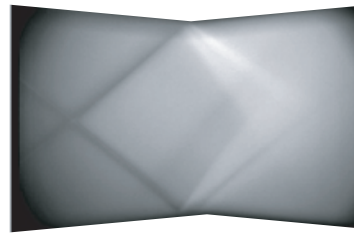

(f) $z=25 \mathrm{~mm}$

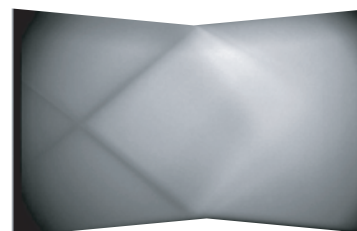

(h) $z=35 \mathrm{~mm}$

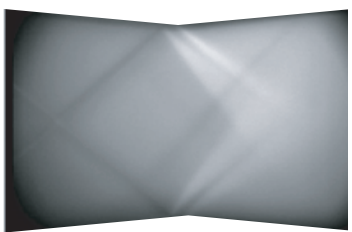

(c) $z=10 \mathrm{~mm}$

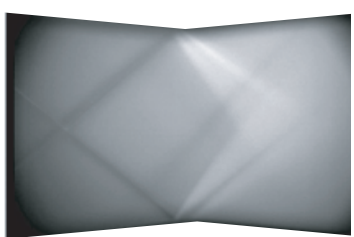

(e) $z=20 \mathrm{~mm}$

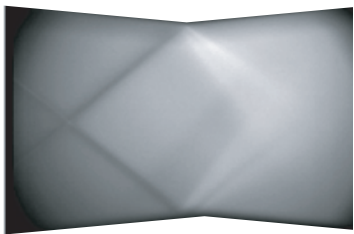

(g) $z=30 \mathrm{~mm}$

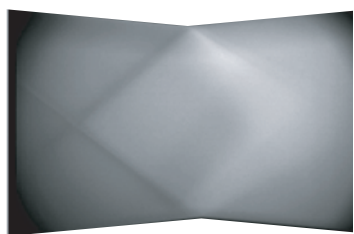

(i) $z=40 \mathrm{~mm}$
第16 図＼cjkstart断層シュリーレン可視化結果

圧縮波が発生している.

第 16 図に断層シュリーレン画像を示す。 $z=0 \mathrm{~mm}$ の位 置では，マッハ線が $x / c=0.25 \sim 0.5$ の間で発生している のがわかる。また不鮮明ではあるが，衝撃波及び膨張波が 全体的に不鮮明になっている。これはフォーカス位置が壁 面境界層内にあるためである。第 13 図に示すシュリーレン 画像では上下の翼からマッハ線が生じている様子を可視化 することができたが, 断層シュリーレン画像では感度が低 いために上翼から発生しているマッハ線は可視化されてい ない。

$z=5 \mathrm{~mm}$ の位置では, 衝撃波, 膨張波及びマッ八線が 徐々に鮮明になり始め, 最終的に $z=10 \mathrm{~mm}$ の位置で鮮 明になっている。このような衝撃波構造は $z=20 \mathrm{~mm}$ の 位置までほぼ同じ構造をしている。

$z=25 \mathrm{~mm}$ の位置ではマッハ線が消え始め, $z=30 \mathrm{~mm}$ 


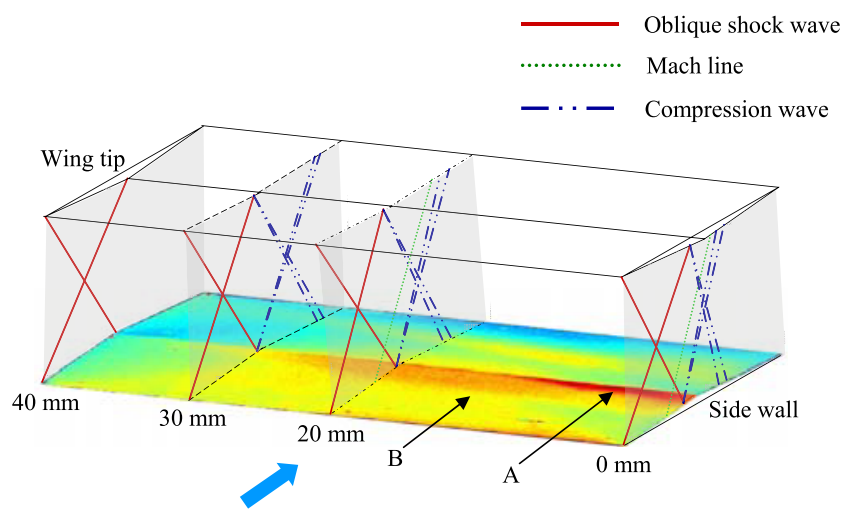

第 17 図 3 次元複葉翼内部の衝撃波構造

の位置で不鮮明になっている.

$z=35 \mathrm{~mm}$ の位置では, 斜め衝撃波と層流境界層により 発生した圧縮波がほぼ見えなくなっていることから，斜め 衝撃波が稜線に到達し, 膨張波によってほぼ相殺されてい ると考えられる。

そして翼端にあたる $z=40 \mathrm{~mm}$ の位置では，翼端に発生 するマッハコーンの領域内であるため理想的な相殺は生じ ていないと考えられるが17,18), 斜め衝撃波が澎張波によっ て相殺されていることがわかる。また第 12 図に示す翼端 位置の圧力分布からも高圧力領域が減少しており, 衝撃波 が相殺されていることがわかる.

これらのスパン方向の各断面画像と PSPによる圧力分 布を基に 3 次元複葉翼内部流れ場を考察する。第 17 図に 3 次元複葉翼内部流れの模式図を示す。なお，視覚的にわか りやすくするため，アスペクト比を調整している。

まず，稜線手前で斜め衝撃波が入射している。これは壁 面境界層の影響によりマッハ数が減少したためと考えられ, この斜め衝撃波が翼面圧力分布上の高圧力領域 $\mathrm{A}$ の原因に なっていると考えられる。 さらに翼内部に焦点を当ててい くと, $z=30 \mathrm{~mm}$ の位置でマッハ線が不鮮明になっている. 一方の圧力分布画像上でも $z=30 \mathrm{~mm}$ の位置で高圧力領 域 B が減少している。この高圧力領域 B はマッハ線背後の 圧力上昇によって生じたと考えられる。また，このマッハ 線はスパン方向にある幅を持って生じている。そして翼端 側では，衝撃波の相殺現象が起こっている，壁面側から翼 端側までの可視化結果より, 斜め衝撃波の到達位置が徐々 に下流に推移していると考えられる。

\section{4. ま と め}

本研究では複葉翼内部流れの解明を目指し，断層シュリー レン光学系の設計・製作を行った. 3 次元試験模型に対し て, これを適用し, 翼間流れ場の 3 次元構造の可視化に成 功した。 また, PSP 計測結果を用いて, 複合的な計測を行 い, 複葉翼模型内部の衝撃波構造を明らかにした。以下に 本研究で得られた結論を述べる。

・断層シュリーレン光学系を用いて 3 次元翼模型内部の可 視化を行い, 壁面側では稜線手前で斜め衝撃波が入射し
ていることがわかった

・壁面側から翼端方向について断層可視化を行った結果, 特 定の位置でマッハ線が不鮮明になり，マッハ線がスパン 方向に対してある幅を持って生じていることがわかった。 ・翼端を観察すると, 斜め衝撃波が膨張波によって相殺さ れており, 斜め衝撃波の到達位置が翼端方向に向かうに つれて，下流に推移していることがわかった。

・断層シュリーレン可視化結果と PSP 計測結果を複合さ せることで, 3 次元複葉翼内部の衝撃波構造をより詳細 に明らかにすることができた。

\section{参 考 文 献}

1) Kusunose, K.: A New Concept in the Development of Boomless Supersonic Transport, First International Conference on Flow Dynamics, 2004, pp. 46-47.

2) Kusunose, K., Matsushima, K., Goto, Y., Yamashita, H., Yonezawa, M., Maruyama, D. and Nakano, T.: A Fundamental Study for the Development of Boomless Supersonic Transport Aircraft, The 44th AIAA Aerospace Sciences Meeting, Reno, 2006.

3) Yamashita, H. and Obayashi, S.: Numerical Investigation on Sonic Boom Reduction with Non-Axisymmetric Body Shapes, The 46th AIAA Aerospace Sciences Meeting and Exhibit, Reno, AIAA Paper 2008-59, 2008.

4) 米沢誠仁, 大林 茂：CFD 解析による有限幅の超音速複葉翼の 空力特性評価, 日本航空宇宙学会論文集, 57 (2009), pp. 32-38.

5) 米沢誠仁, 山下 博, 大林 茂: 超音速複葉翼に扔ける超音速流 れの履歴現象の 2 次元 CFD 解析, 日本航空宇宙学会論文集, $\mathbf{5 7}$ (2009), pp. 131-133.

6) Maruyama, D., Kusunose, K. and Matsushima, K.: Aerodynamic Characteristics of a Two-Dimensional Supersonic Biplane, Covering Its Take-Off to Cruise Conditions, Shock Waves, 18 (2009), pp. 437-450.

7) Liu, T. and Sullivan, J. P.: Pressure and Temperature Sensitive Paints, Springer, Berlin, Heidelberg, New York, 2004.

8）浅井圭介：感圧塗料による圧力分布の計測技術，可視化情報学会 誌, 18 (1998), pp. 97-103.

9) Nagai, H., Naraoka, R., Sawada, K. and Asai, K.: PressureSensitive Paint Measurement of Pressure Distribution in a Supersonic Micronozzle, AIAA J., 46 (2008), pp. 215-222.

10) Nagai, H., Oyama, S., Asai, K., Fujisono, T. and Obayashi, S.: Three Dimensional Effect of a Supersonic Busemann Biplane on Start Process, 27th International Symposium on Space Technology and Science, 2009-e-21, 2009.

11) Kantrowitz, A. and Trimpi, R. L.: A Sharp-Focusing Schlieren System, J. Aeronaut. Sci., 17 (1950), pp. 311-314, 319.

12）樫谷賢士, 山口 裕, 須田武志, 北野秀樹：ロッド拡散光源を有 するフォーカシングシュリーレン装置による二重くさび翼型まわ りの観察, 可視化情報学会論文集, 27 (2007), pp. 113-120.

13) Settles, G. S.: Schlieren \& Shadowgraph Techniques, 1st ed, Springer, Berlin, 2001, pp. 92-98.

14) Weinstein, L. M. : An Improved Large-Field Focusing Schlieren System, The 29th AIAA Aerospace Sciences Meeting, Reno, 1991.

15) Amao, Y., Asai, K., Miyashita, T. and Okura, I.: Photophysical and Photochemical Properties of Optical Oxygen Pressure Sensor of Platinum Porphyrin-IsobutylmethacrylateTrifluoroethylmethacrylate Copolymer Film, Polymer J., 31 (1999), pp. 1267-1296.

16) 生井武文, 松尾一泰: 衝撃波の力学, コロナ社, 東京, 1983.

17) Tan, H. S.: The Aerodynamics of Supersonic Biplanes of Finite Span, Wright Air Development Center, TR 52-276, Dayton, 1950.

18) Sears, W. R. and Tan, H. S.: The Aerodynamics of Supersonic Biplane, Quart. Appl. Math., 9 (1951), pp. 67-76. 